\title{
À propos des débuts de la presse musulmane du Sud-est européen
}

Alexandre Popović

\section{(2) OpenEdition}

Journals

Édition électronique

URL : http://journals.openedition.org/etudesbalkaniques/437

ISSN : 2102-5525

\section{Éditeur}

Association Pierre Belon

\section{Édition imprimée}

Date de publication : 1 janvier 2001

Pagination : 79-87

ISBN : 2-910860-10-8

ISSN : $1260-2116$

\section{Référence électronique}

Alexandre Popović, «À propos des débuts de la presse musulmane du Sud-est européen », Études balkaniques [En ligne], 8 | 2001, mis en ligne le 08 avril 2009, consulté le 24 avril 2019. URL : http:// journals.openedition.org/etudesbalkaniques/437

Ce document a été généré automatiquement le 24 avril 2019

Tous droits réservés 


\section{À propos des débuts de la presse musulmane du Sud-est européen}

Alexandre Popović

AUTEUR

ALEXANDRE POPOVIĆ

C.N.R.S.-Paris 